Biospecies Vol. 11 No. 1, January 2018

\title{
Penggunaan Beberapa Metode Ekstraksi Pada Rimpang Curcuma Untuk Memperoleh Komponen Aktif Secara Kualitatif
}

\author{
(Use of Multiple Methods of Extraction on Curcuma Rhizomes To Acquire Qualitative \\ Active Component)
}

\author{
Yurleni \\ Animal Production and Technology, Faculty of Animal Science, Jambi University. Jambi \\ Indonesia. Phone +6281274601119 . \\ E-mail: lenifaisal@yahoo.com
}

\begin{abstract}
This study aims to compare several extraction methods to obtain the active component of the qualitative Curcum rhizome. The data obtained were analyzed using descriptive analysis. Curcuma rhizome used comes from 4 types of plants Curcuma xanthorriza (temulawak), Curcuma domestica (turmeric), Curcuma mango (temu mangga) and Curcuma zedoaria (temu putih). The extraction method used consisted of maseration, reflux and soxhlet method. From the research result it was found that all three extraction methods can be used (maceration, soxhletasi and reflux) to extract the curcuma rhizomes. The result of phytochemical test of metabolite secondary detectable and very strong both of atsiri and non-essential oil group is using reflux method then new method of soxhletasi and then maceration method.
\end{abstract}

Keywords: extraction, curcuma, phytochemical, qualitative.

\begin{abstract}
Abstrak
Penelitian ini bertujuan untuk membandingkan beberapa metode ekstraksi untuk memperoleh komponen aktif pada rimpang Curcumasecara kualitatif. Data yang diperoleh dianalisis menggunakan analisis deskriptif. Rimpang curcuma yang digunakan berasal dari 4 jenis tanaman yaitu Curcuma xanthorriza (temulawak), Curcuma domestica (kunyit), Curcuma mangga (temu mangga) dan Curcuma zedoaria (temu putih). Metode ekstraksi yang digunakan terdiri dari metode maserasi, refluk dan soxhlet.Dari hasil penelitian didapat bahwa ketiga metode ekstraksi dapat digunakan (maserasi, soxhletasi dan refluks) untuk mengekstrak rimpang curcuma. Hasil uji skrining fitokimia zat metabolit sekunder yang terdeteksi kuat dan sangat kuat baik dari golongan minyak atsiri dan non atsiri adalah menggunakan metode refluks kemudian baru metode soxhletasi dan selanjutnya metode maserasi.
\end{abstract}

Kata kunci: ekstraksi, curcuma,fitokimia, kualitatif.

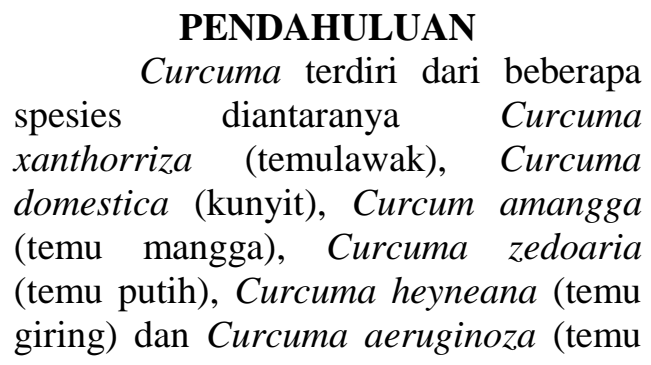

hitam) (Tjitrosoepomo, 1994). Spesiesspesies dari Curcuma ini memilki kesamaan komponen kimia kurku minoid, flavonoid dan minyak atsiri yang berpotensi sebagai antioksidan (Depkes,1995). Keberadaan gugusan phenolik pada senyawa yang dikandung 
Curcuma menyebabkan aktifitas yang kuat pada sistem biologis (Ahsan, 1998)

Potensi pemanfaatan rimpang Curcuma sebagai sumber antioksidan dalam pakan ternak ruminansia, informasinya masih sangat kurang. Industri yang mengolah rimpang curcuma umumnya menggunakan metode melalui penggodokan untuk mendapatkan campuran yang berkhasiat. Metode yang dipakai sebagian besar menggunakan air sebagai pelarut. Hal ini kurang efektif karena banyak senyawa aktif yang tidak larut dengan baik di dalam air. Oleh karena itu pemilihan metode ekstraksi sangat penting untuk mendapatkan komponen yang terekstrak.

Pakan yang mengandung sumber antioksidan akan dapat meningkatkan kecernaan di dalam rumen serta meningkatkan respon fisologis dan pertambahan bobot badan ternak. Sumber antioksidan antara lain vitamin $\mathrm{C}$, beta karotin, saponin, phenol dan flavonoid (Mardalena, 2012; Mardalena et al., 2011, 2013). Komponen antioksidan yang berperan dalam meningkatkan kecernaan di dalam rumen diantaranya adalah kurkuminoid dan saponin. Dilaporkan oleh Suharti et al. (2008) bahwa pemberian $0,18 \%$ ekstrak lerak yang mengandung saponin dalam ransum mampu menurunkan populasi protozoa dan meningkatkankan populasi total bakteri di dalam rumen sehingga jumlah pakan yang dapat difermentasi oleh bakteri semakin meningkat dan mengakibatkan peningkatan nilai kecernaan bahan kering sebesar 6,06\% dan bahan organik sebesar 6,32\%.

Berdasarkan uraian tersebut, maka perlu dilakukan penelitian mengenai berbagai metode ekstraksi guna penarikan komponen/zat aktif, analisis kandungan zat aktif dari masingmasing rimpang Curcuma dari dari berbagai metode ekstraksi.

\section{METODOLOGI PENELITIAN}

Penelitian ini dilakukan pada tanggal 20 Juli- 14 September di Laboratorium terpadu Universitas Jambi dan Laboratorium Farmasi Fakultas Farmasi Universitas Padjajaran, Bandung

\section{Alat dan Bahan}

Bahan kimia yang digunakan adalah pereaksi mayer, pereaksi dragendorff, besi (III) klorida, serbuk $\mathrm{Mg}$, asam klorida, amyl alcohol, natrium hidroksida, larutan gelatin, larutan vanillin $10 \%$, asam sulfat, pereaksi Lieberman-Burchard.Rimpang Curcuma segar yang diperoleh dari pasar Angso duo Jambi terdiri dari Curcuma xanthorriza (temulawak), Curcuma domestica (kunyit), Curcum amangga (temu mangga) dan Curcuma zedoaria (temu putih).

Alat yang digunakan pada penelitian adalah ekstraksi soxhlet, labu didih dasar bulat, kondensor, statif, selang kecil, kertas saring, batu didih, heating mantle, thermometer, balance, hot plate, boiling flash berleher, rotary evaporator, cawan porselen, oven, eksikator, maserator, radas penguap berputar, tanur, neraca analitik.

\section{Metode Penelitian}

Penelitian ini dilakukan dengan beberapa tahapan yaitu: persiapan sampel, ekstraksi sampel dan uji fitokimia, penentuan kadar air dan kadar abu.

\section{Persiapan sampel}

masing-masing sebanyak $3 \mathrm{~kg}$ rimpang Curcuma dicuci bersih sebelum dilakukan penelitian. kemudian dilakukan pengecilan ukuran rimpang sampai ketebalannya $\pm 5-7 \mathrm{~mm}$, dan dikeringkan dibawah sinar matahari secara tidak langsung sampai diperoleh kadar air yang relatif rendah ( \pm 7 hari). Setelah itu, rimpang yang sudah kering digiling halus menggunakan Willey mill kemudian diayak menggunakan pengayak 200 mesh. Selanjutnya sampel siap untuk dianalisa.

\section{Ekstraksi}


Ekstraksi curcuma dilakukan menggunakan pelarut etanol $80 \%$. Ekstraksi dilakukan dengan cara maserasi, refluk dan soxletasi. Penggunaan tiga metode ekstraksi dimaksudkan untuk mendapatkan satu metodeekstraksi yang dapat mengekstrak komponen aktif yang tepat. Metode ekstraksi tersebut meliputi:

\section{a. Metode maserasi}

Curcuma yang telah halus diambil sebanyak $25 \mathrm{~g}$ kemudian direndam dengan $50 \mathrm{ml}$ pelarut organik (non polar) dan disimpan semalam pada suhu refrigerasi.Campuran pelarut dan curcuma dipisahkan menggunakan kertas saring.Kemudian ditambahkan natrium sulfat anhidrat kedalam ekstrak solven untuk terbebas dari air. Filtrate yang didapat pada kertas saring dipekatkan dengan destilasi fraksional menggunakan kolom vigreux dengan suhu $5^{\circ} \mathrm{C}$ lebih tinggi dari titik didih pelarut yang digunakan.

\section{b. Metode soxhlet}

Ekstraksi soxhlet adalah salah satu instrumen yang digunakan untuk mengekstrak suatu senyawa. Pada umumnya metode yang digunakan dalam instrumen ini adalah untuk mengekstrak senyawa yang memiliki kelarutan terbatas dalam suatu pelarut. Dalam proses ekstraksi ini harus tepat untuk memilih pelarut yang akan digunakan. Pelarut yang baik untuk ekstraksi adalah pelarut yang mempunyai daya melarutkan yang tinggi terhadap zat yang diekstraksi. Daya melarutkan berhubungan dengan kepolaran pelarut dan kepolaran senyawa yang diekstraksi (like dissolved like).

\section{Cara Kerja :}

Curcuma halus ditempatkan pada kertas saring dan diletakkan didalam soxhlet. Soxhlet disambungkan dengan Labu dasar bulat yang telah diisi pelarutdan batu didih yang dihubungkan dengan Kondensator. Pelarut yang digunakan mudah mendidih, lalu gas (uap) melewati tabung lalu akan dikondensasikan oleh kondensator, dan pelarut yang akan dikondensasikan jatuh kedalam "Porous Thimble" dan secara perlahan mengisi bagian dari soxhlet, ketika pelarut mencapai puncak pipa, maka pelarut tersebut akan kembali ke labu. Proses ini akan terulang secaraotomatis sampai ekstraksi selesai.

\section{c. Metode refluks}

Metode Reflux merupakan metode ektraksi dengan cara panas (membutuhkan pemanasan pada prosesnya), secara umum pengertian refluks sendiri adalah ekstraksi dengan pelarut pada temperatur titik didihnya, selama waktu tertentu dan jumlah pelarut yang ralatif konstan dengan adanya pendingin balik (Depkes RI, 2000). Ekstraksi dengan cara ini adalah berkesinambungan. Metode ini umumnya digunakan untuk mensintesis senyawa-senyawa yang mudah menguap atau volatile. Pada kondisi ini jika dilakukan pemanasan biasa maka pelarut akan menguap sebelum reaksi berjalan sampai selesai. Prinsip dari metode refluks adalah pelarut volatil yang digunakan akan menguap pada suhu tinggi, namun akan didinginkan dengan kondensor sehingga pelarut yang tadinya dalam bentuk uap akan mengembun pada kondensor dan turun lagi ke dalam wadah reaksi sehingga pelarut akan tetap ada selama reaksi berlangsung.

Cara Kerja :

1. Ditimbang sampel sebanyak $50 \mathrm{gr}$

2. Masukkan sampel ke dalam labu alas bulat

3.Masukkan methanol hingga semua sampel terendam

4. Pasang labu alas bulat pada alat refluks yang telah dihubungkan dengan kondensor

5. Panaskan sampel selama 1 jam

6. Saring ekstrak yang diperoleh dengan kertas saring

7. Filtrat diuapkan untuk menghilangkan pelarutnya menggunakan rotary evaporator sehingga diperoleh ekstrak curcuma.

2. Uji Fitokimia. Uji yang dilakukan terdiri atas uji flavonoid, alkaloid, steroid, terpenoid, tanin, dan saponin (Harborne 1996). 
a. Uji Flavonoid dan Saponin. Sebanyak $10 \mathrm{~mL}$ ekstrak ditambah $0.5 \mathrm{~g}$ serbuk $\mathrm{Mg}, 0.2 \mathrm{~mL} \mathrm{HCl}$ dan $2 \mathrm{~mL}$ amil alkohol lalu dikocok. Jika lapisan amil alkohol menjadi berwarna cokelat maka positif terdapat flavonoid. Uji saponin dilakukan dengan pengocokan $10 \mathrm{~mL}$ filtrat dalam tabung reaksi tertutup selama 10 detik. Adanya saponin ditunjukkan dengan terbentuknya buih yang stabil.

b.Uji Alkaloid.

Sebanyak $1 \mathrm{~g}$ ekstrak ditambah $10 \mathrm{~mL}$ $\mathrm{CHCl}_{3}$ dan beberapa tetes $\mathrm{NH}_{4} \mathrm{OH}$.

Kemudian larutan disaring dan ekstrak yang dihasilkan dikocok dengan 10 tetes $\mathrm{H}_{2} \mathrm{SO}_{4} 2 \mathrm{M}$. Lapisan asamnya diambil dan ditambah pereaksi Mayer, Wagner, dan Dragendorf. Hasil uji akan positif apabila terbentuk endapan putih ketika direaksikan dengan pereaksi Mayer, endapan cokelat dengan pereaksi Wagner, dan endapan merah jingga dengan pereaksi Dragendorf.

c.Uji Tanin.

Sebanyak $4 \mathrm{~mL}$ ekstrak dipanaskan selama 10 menit lalu disaring. Filtrat yang diperoleh ditambah $\mathrm{FeCl}_{3} 1 \%$ atau larutan gelatin, jika dihasilkan warna biru tua atau hijau maka hasil uji positif terhadap tanin.

\section{d.Uji Steroid dan Terpenoid.}

Bahan diekstraksi dengan $10 \mathrm{~mL}$ etanol panas lalu disaring dan diuapkan sampai kering. Residu yang diperoleh dilarutkan dalam eter dan disaring kembali sehingga diperoleh dua bagian larut eter dan residu. Bagian yang larut eter langsung diuji dengan dua tetes asam asetat anhidrat dan $\mathrm{H}_{2} \mathrm{SO}_{4}$. Residu dilarutkan kembali ke dalam $\mathrm{HCl} 2 \mathrm{~N}$ dan disaring lagi, residu yang diperoleh ditambah eter dan dilakukan uji yang sama. Uji positif ditunjukkan dengan warna biru atau hijau untuk steroid dan merah ungu untuk terpenoid.

\section{Analisis Statistik}

Data yang diperoleh dianalisis menggunakan analisis deskriptif.

\section{HASIL DAN PEMBAHASAN}

\section{Uji skrining fitokimia rimpang} curcuma

Uji fitokimia bertujuan untuk mengetahui kandungan senyawa metabolit sekunder pada keempat rimpang curcuma (temulawak, kunyit, temu mangga dan temu putih) akibat pengaruh metode ekstraksi yang berbeda (maserasi, soxhlet dan refluks).Ekstrak yang dihasilkan mengandung senyawa minyak atsiri dan non atsiri.Senyawa metabolit sekunder non atsiri yang digunakan sebagai tolak ukur penggunaan ketiga metode adalah alkaloid, polifenol, flavonoid, saponin, kuinon, tannin dan steroid sedangkan kandungan minyak atsiri adalah monoterpen/sesquiterpen dan triterpenoid.

Curcuma atau empon-emponan adalah anggota familia Zingiberaceae dan menghasilkan minyak atsiri.Minyak atsiri kebanyakan tergolong terpenoid dan minyak atsiri sendiri adalah suatu campuran senyawa yang mudah menguap (Hegarty dkk, 2001). Minyak atsiri sangat penting sebagai penyedap rasa dan sumber obat (Lata dkk., 2000). Kandungan minyak atsiri berbeda-beda untuk setiap jenis rimpang curcuma.

\section{a. Rimpang Temu Putih}

Hasil uji skrining fitokimia menggunakan metode ekstraksi maserasi, soxhlet dan refluks pada rimpang temu putih disajikan pada Tabel 1. 
Tabel 1.Hasil uji skrining fitokimia menggunakan metode ekstraksi maserasi, soxhlet dan refluks pada rimpang temu putih.

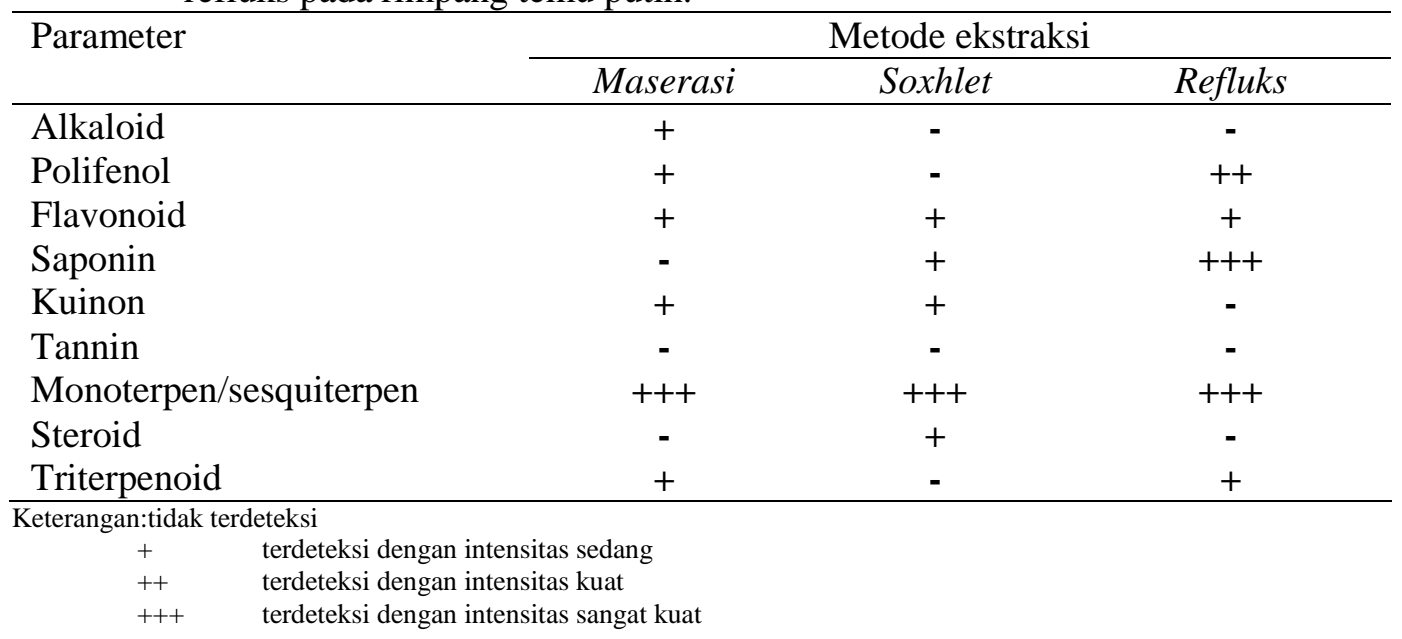

Dari hasil uji skrining fitokimia, zat metabolit sekunder yang terdeteksi kuat dan sangat kuat pada rimpang temu putih menggunakan ketiga metode ekstraksi baik pada kandungan minyak atsiri dan non atsiri adalah menggunakan metode refluks. Panggunaan metode refluks menghasilkan senyawa monoterpen/sesquiterpen, polifenol dan flavonoid yang terdeteksi kuat dan sangat kuat. Kandungan minyak atsiri temu putih berkisar 1,0-1,5\% (Setyawan 2003), terdiri dari moneterpen dan seskuiterpen. Monoterpen berkhasiat sebagai anti kanker (antineoplastik) dimana zat ini dapat menonaktifkan pertumbuhan sel kanker payudara dan seskuiterpen sebagai komponen utamanya (Rita 2010). Selain minyak atsiri, temu putih juga mengandung flavonoid, saponin, polifenol dan triterpenoid (Hembing 2004 dan Syukur 2004). Senyawa sesquiterpen, salah satu kelompok minyak atsiri yang bernilai tinggi untuk taksonomi, karena umumnya sangat khas untuk spesies tumbuhan tertentu, sehingga dapat membedakan spesies, populasi bahkan individu (Setyawan 2003)

Selain kandungan minyak atsiri, zat metabolit sekunder yang berfungsi sebagai Golongantriterpenoid terdeteksi dengan intensitas sedang pada penggunaan metode ekstraksi maserasi dan tefluks sedangkan zat metabolit kuinon dihasilkan dari metode ekstraksi maserasi dan soxhlet. Komponen utama senyawa metabolit sekunder rimpang temu putih termasuk kedalam golongan flavonoid, polifenol dan triterpenoid (Rita 2010).

\section{b. Rimpang Temu Mangga}

Zat metabolit sekunder yang dikandung oleh rimpang temu mangga dari ketiga metode ekstraksi disajikan pada Tabel 2 
Tabel 2.Hasil uji skrining fitokimia menggunakan metode ekstraksi maserasi, soxhlet dan refluks pada rimpang temu mangga.

\begin{tabular}{lccc}
\hline Parameter & \multicolumn{3}{c}{ Metode ekstraksi } \\
\cline { 2 - 5 } & Maserasi & Soxhlet & Refluks \\
\hline Alkaloid & - & - & - \\
Polifenol & - & - & + \\
Flavonoid & + & + & + \\
Saponin & ++ & - & +++ \\
Kuinon & + & - & + \\
Tannin & - & - & - \\
Monoterpen/sesquiterpen & + & - & - \\
Steroid & + & & - \\
Triterpenoid & - & & + \\
Keterangan:tidak terdeteksi & terdeteksi dengan intensitas sedang \\
\multicolumn{1}{r}{++} & terdeteksi dengan intensitas kuat & &
\end{tabular}

Kandungan minyak atsiri pada temu mangga berkisar $2-2,5 \%$ (Setyawan 2003). Sejauh ini penelitian mengenai Curcuma mangga Val. masih banyak berkisar mengenai potensinya sebagai antikanker (Yuandani dkk., 2011), inhibitor virusdengue-2 NS2B/NS3 protease (Kiat dkk., 2006), antioksidan dan antibakteri(Policegoudra, 2007), inhibitor senyawa NO (Kaewkroek, 2009), antimicrobial (Philip dkk., 2009), dan antialergi (Tewtrakul \& Subhadhirasakul,2007). Sedangkan metode yang digunakan untuk menghasilkan minyak atsiri dan non atsiri pada temu mangga masih sangat sedikit sekali.Senyawa yang terdeteksi sedang dan kuat pada golongan minyak atsiri adalah monoterpen/sesquiterpen sedangan yang termasuk golongan non atsiri yang terdeteksi kuat dan sangat kuat adalah senyawa saponin.Dari ketiga metode ekstraksi yang digunakan untuk menghasilkan kandungan minyak atsiri maupun non atsiri yang kuat dan sangat kuat yang terbaik adalah menggunakan metode refluks.

\section{c. Rimpang Kunyit}

Hasil uji skrining fitokimia pada rimpang kunyit yang diekstraksi dengan metode maserasi, soxhlet dan refluks disajikan pada tabel 3. Kandungan minyak atsiri pada kunyit berkisar 1,5$2,5 \%$ (Setyawan 2003). Sebagai penyedap rasa dan sumber obat, minyak atsiri bernilai ekonomis penting (Lata dkk., 2000). Selain memberi rasa, minyak atsiri juga digunakan memberi aroma makanan, minuman, parfum dan kosmetik (Hegarty dkk., 2001). Sifat toksik alami minyak atsiri berguna dalam pengobatan (Liu dkk., 1998). Metabolit sekunder merupakan sumber utama senyawa obat (Harvey, 2000). Senyawa metabolit sekunder baik dari golongan minyak atsiri dan non atsiri yang terdeteksi kuat dan sangat kuat menggunakan ke tiga metode diatas adalah senyawa polifenol, flavonoid, kuinon, monoterpen/sesquiterpen dan triterpenoid. Metode terbaik yang digunakan untuk menghasilakn senyawa tersebut adalah menggunakan metode soxhletasi dan refluks. 
Tabel 3.Hasil skrining fitokimia menggunakan metode ekstraksi maserasi, soxhlet dan refluks pada rimpang kunyit.

\begin{tabular}{lccc}
\hline Parameter & \multicolumn{3}{c}{ Metode ekstraksi } \\
\cline { 2 - 4 } & Maserasi & Soxhlet & Refluks \\
\hline Alkaloid & - & - & - \\
Polifenol & ++ & ++ & ++ \\
Flavonoid & ++ & ++ & ++ \\
Saponin & - & - & ++ \\
Kuinon & ++ & ++ & + \\
Tannin & - & - & - \\
Monoterpen/sesquiterpen & + & - & - \\
Steroid & - & ++ & ++ \\
Triterpenoid & + & & ++ \\
Keterangan:tidak terdeteksi & terdeteksi dengan intensitas sedang \\
\multicolumn{1}{c}{++} & terdeteksi dengan intensitas kuat & & \\
\multicolumn{1}{l}{++} & terdeteksi dengan intensitas sangat kuat & &
\end{tabular}

\section{d. Rimpang Temulawak}

Kandungan metabolit sekunder

pada rimpang temulawak dari uji skrining fitokimia dapat dilihat pada Tabel 4.

Tabel 4.Hasil uji skrining fitokimia menggunakan metode ekstraksi maserasi, soxhlet dan refluks pada rimpang temulawak.

\begin{tabular}{lccc}
\hline Parameter & \multicolumn{3}{c}{ Metode ekstraksi } \\
\cline { 2 - 4 } & Maserasi & Soxhlet & Refluks \\
\hline Alkaloid & - & - & - \\
Polifenol & - & + & + \\
Flavonoid & + & + & + \\
Saponin & - & - & - \\
Kuinon & ++ & + & ++ \\
Tannin & - & - & - \\
Monoterpen/sesquiterpen & + & ++ & ++ \\
Steroid & - & ++ & ++ \\
Triterpenoid & tidak terdeteksi+ & terdeteksi dengan intensitas sedang & \\
Keterangan: & t+ & terdeteksi dengan intensitas kuat+++terdeteksi dengan intensitas sangat kuat &
\end{tabular}

Komponen aktif utama yang terdapat dalam temulawak adalah xantorhizol dan kurkuminoid. Xanthorrizol, zingiberen, $\beta$-kurkumin, ar-kurkumin, atlantan, turmeron, arturmeron,dan isofuranogermakren adalah komponen minyak atsiri temulawak yangdiisolasi dengan cara ekstraksi oleh pelarut (Malingre 1971). Kandungan minyak atsiri temulawak 2-2,5\% (Setyawan 2003). Xanthorrizol termasuk dalam golongan seskuiterpen (Hwang 2006) dan dapat digunakan sebagai agen potensial antibakteri pembentukan biofilm oleh Streptococcus mutans
(Rukayadi \& Hwang 2006).Sidik $d k k$.(1992) menyatakan bahwa rimpang curcuma sebagian besar terdiri dari pati yang biasa digunakan sebagai bahan makanan, kurkuminoid dan minyak atsiri. Kurkuminoid memberikan warna kuning pada rimpang. Kurkuminoid terdiri dari zat kurkumin dan desmetoksi kurkumin sedangkan minyak atsiri menyebabkan aroma bau khas aromatik. Kandungan minyak atsiri curcuma adalah xantorrhizol.Uji yang sangat penting dilakukan pada ekstrak rimpang curcuma ini adalah uji terpenoid karena 
xantorrhizol merupakan salah satu senyawa terpenoid yaitu seskuiterpen.

Pada tabel 4 dapat dilihat bahwa komponen metebolit sekunder baik yang tergolong minyak atsiri dan non atsiri yang terdeteksi dengan intensitas kuat dan sangat kuat yaitu pada senyawa terpenoid baik monoterpen, sesquiterpen, triterpenoid dan kuinon. Dilihat dari senyawa yang terdeteksi kuat dan sangat kuat pengunaan metode soxhletasi dan refluks sangat baik.

\section{KESIMPULAN}

Ketiga metode ekstraksi dapat digunakan (maserasi, soxhletasi dan refluks) untuk mengekstrak rimpang curcuma.Hasil uji skrining fitokimia zat metabolit sekunder yang terdeteksi kuat dan sangat kuat baikdari golongan minyak atsiri dan non atsiri adalah menggunakan metode refluks kemudian baru metode soxhletasi dan selanjutnya metode maserasi.

\section{Ucapan Terimakasih}

Terimakasih penulis ucapkan kepada DP2M Dikti Kementerian Riset, Teknologi dan Pendidikan Tinggi yang telah membiayai penelitian skim Penelitian Fundamental ini.

\section{DAFTAR PUSTAKA}

Ahsan, H., N. Parveen, N.U. Khan and S.M. Hadi. 1999. Pro-oxidant, Antioxidant and Cleavage Activities on DNA of Curcumin and Its Derivaties Demetho xycurcumin and Bisde methoxycurcumin. Chem-Biol Interact. 121 pp: $161-175$.

Departemen Kesehatan Republik Indonesia. 1995. Inventaris Tanaman Obat ndonesia. Edisi I. Badan Penelitian dan Pengembangan Kesehatan. Jakarta.

Hegarty, M.P, E.E. Hegarty, and R.B.H. Wills. 2001. Australian Plant Bushfoods. Kingston: Rural Industries Research and Development Corporation.
Lata K., S. Mande S, and V.V.N. Kishore. 2000. Studies on Quality Improvement of LargeCardamom using an Advanced Gasifier based Dryer. New Delhi: Tata Energy Research Institute.

Llyod LE, McDonald BE, Crampton EW. 1978. Fundamentals of Nutrition. Second Edition. W. H. Freeman and Company. San Francisco.

Mardalena, L. Warly, E. Nurdin, R.W.R. Ningrat and Farizal. 2011. Milk Quality of Dairy Goat by Giving Feed Supplement as Antioxidant Source. J. Ind. Trop. Animal Agric. 36 (3): 205-211.

Mardalena. 2012. Evaluasi Pakan Suplemen Sebagai Sumber Antioksidan dan Pengaruhnya Terhadap Respon Fisiologis dan Produktifitas Kambing Perah Peranakan Etawah. Disertasi. Univ. Andalas. Padang.

Mardalena, L. Warly, E. Nurdin, R.W.R. Ningrat and S. Novianti. 2013. Feed Supplement Evaluation of Pineapple Rind ((Ananas comosus L. Merr) and Micro Mineral as Antioxidant Source to Rumen Fermentation of Etawah Dairy Goats. J. Ind. Trop. Animal Agric.

Rita W S. 2010. Isolasi, identifikasi dan uji aktivitas antibakteri senyawa golongan triterpenoid pada rimpang temu putih (Curcuma zedoaria (Berg.)Roscoe).Jurnal kimia.

Setyawan A D. 2003. Keanekaragaman kandungan minyak atsiri rimpang temu-temuan (curcuma).Biofarmasi 1(2): 44-49.

Sidik, Mulyono MW, Muhtadi A. 1985. Temulawak (Curcuma xanthorrhiza Roxb.). Jakarta: Yayasan Pengembangan Obat Bahan Alam Phytomedica.

Suharti, S., A. Kurniati, D.A. Astuti and E. Wina. 2008. Microbial Population And Fermentation 
Characteristic in Respone to Sapindus rarak Mineral Blok Suplementation. Media Peternakan : 150 - 154.
Syukur, C., 2004, Temu Putih Tanaman Obat Antikanker, Swadaya, Jakarta

Tjitrosoepomo, G. 1994. Taksonomi Tanaman Obat-obatan. UGM, Yogyakarta. 